\title{
Toshio Ishibashi: On the Methodology for the Epidemiological Study of Heart Disease
}

\section{心臟病の疫学的方法論に関する研究}

\author{
日本医科大学衡生学教室（教授：八田貞義）

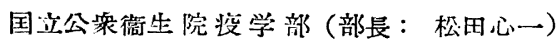

石橋敏男

\section{第 1 章 緒論}

わが国死因別死乞率の年次的推移を観察す ると，昭和 25 年を境として著しい変化を示し ている．即ち昭和 25 年に於ては結核を第 1 位 として以下中枢神経系の血管損傷，胃腸炎， 悪性新生物, 老衰, 肺炎の順で心臟疾患性第7 位に過ぎなかつたのであるが，昭和 26 年では 結核が第 1 位を退き中枢神経系の 血管損傷が 之に代つた。更に昭和 30 年に至ると中枢神経 系の 血管損傷は依然第 1 位を占めている他, 心臓疾患が第 4 位と上年し 結核死亡を上廻る に至つた，要するに心臓疾患に中枢神経系の 血管損傷を合わせた所謂循環系疾患は最重要 の死亡原因をなしているのである。人口構成 の老令化にともない欧米に打けるが如く，こ れらいわゆる老人病が 今後公衆衛生上い吹い よ重要性を加えることは明かである.

1955 年, 国連の報告によると, 36 ケ国中, 心臓疾患死亡を原因の第一とする国は39を数 える1)。ニニージーランドでは総死亡の $40 \%$ が心臓疾患である３0\%を越える国は，オ一 ストラリア，米国，英国，カナダ等であり， 一方わが国ではいかなる理由か総死亡の $8 \%$ を占めるにすぎない。このような差の現われ る原因の一つとして,「病名のつけ方」「死亡 診断の確かさ」等が勿論考慮されなければな らない。然し死亡統計にみられる両者の開き はあまりにも大きく，欧米より心臟疾患死乞 が少ないことは確かな事実のように思われる。 このような比較の資料としては種々のものが
あげられる、結局今日では死後解剖所見が最 も信頼性のあるものとされているのであるが， 特定の者だけが解剖に附せられる今日，これ によつて疫学的な考察を行うことには色々な 難点がある.従つて「心臟病の疫学」に際して は観察の示慓の壳らび方を含めた方法論がま づ確定される必要があると考觉られる。著者 は過去数年間，都市及び農村の種々な集団に ついて, 死亡統計， $X$ 線所見，心電図所見等 の様々な示標を用いて, 心藏病の疫学的研究 を実施してわが国に於ける心蔵病の発生頻度 及びそれに影響を及ぼす諸因子の考察を行つ ているが，それらの実例に基いて心藏病の疫 学に括ける方法論に検討を加兄てみたいと思 5 .

\section{研究対象及び資料}

1. 厚生省統計調査部: 人口動態統計, 昭和 25 年 30 年.

2. 埼玉県比企郡高坂村住民, 2397 名に対す る集団検診.

3. 川崎市内某鉄工場男子従業員 301 名に対 する循環器を主とする集団検診, 昭和 31 年6月。

4. 都内某病院来院者, 白人と日本人各々 145 名に対する 検䛦, 昭和 30 年〜昭和 32 年.

5. 都内某デパート来店者 285 名に対する心 電図検查，昭和 32 年 2 月 10 日 17 日.

6. 朝日クリニックカーによる 344 名に対す る街頭検診, 昭和 32 年 9 月 19 日～21日， 
老人の日。

7. 都下 北多祭郡小平町住民 30 才以上に対 する循環器を主とする集団検診。

8. 埼玉県加須市, 北葛飾郡松伏村, 北埼玉 郡千代田村に於ける成人病検診, 昭和 32 年11月。

\section{第2章＼cjkstart死亡統計による疫学的観察と その方法論的意義}

\section{1. 緒言}

心藏病の疫学的観察の資料としては，死し 統計, 䍜病統計, 集団検診統計等があるが, まづ死亡統計の意義について考察してみる。 心臓病の疫学的研究におたつて死亡統計が重 視さるべき理由は，匡民保健上どの程度の重 要性をもつているかを判断する最も有力な資 料であることである。発生頻度の変化が年々 どのように推移しているかを考察する場合に もこれを資料にせさるを得ない。国民全体を 包含する罹病統計, 集団検診統計の作成が困 難である以上，種々な集団間の心臓病発生頻 度の差異の考察にも欠くべからざる意義を有 乙ている.かっる見地から著者は昭和 25 年か ら 30 年迄, 最近 6 ケ年間の人口動態統計 2 亿 掲げられている心臟病死亡の疫学的特徴につ いて詳細な検討を行つた。

\section{2. 観察の実例}

i) 年次

心臓病はわが国では第 4 位の 死因であるが
欧米諸外国と死亡順位を比較すれば，表 1 に 示す如くで． 殆んど大部分の国は圧倒的な率 で心臟病が第 1 位の死因をなしている。しか しわが国でも総死亡に対する心蔵疾患による 死亡の割合を年次的に観察すると，昭和 10 年 では $3.4 \%$ ，昭和 22 年は $4.3 \%$ となり 昭和 31 年には $8.2 \%$ と最近增加の傾向を示している (図 1).

図 1 心硐疾患死亡数子総死亡に 対する割合の年次推移

(炤和 25 年 29 年)

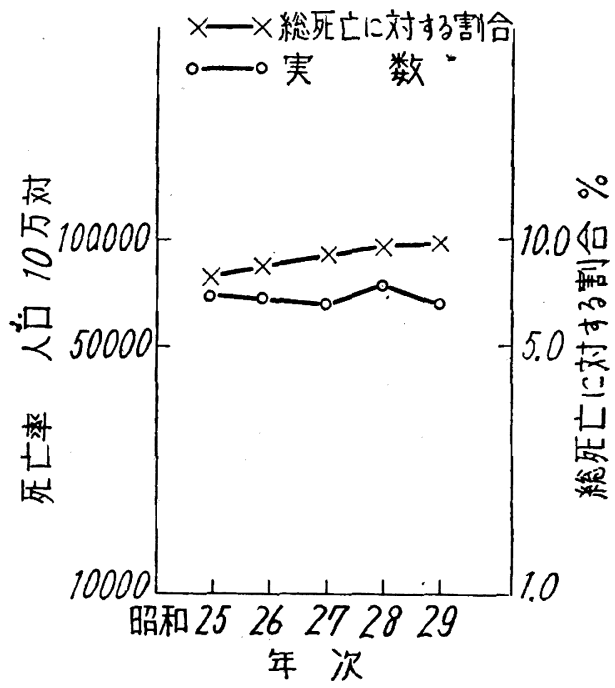

ii）年令

心蔵病の死亡率は総死亡率と同様に 10 才以 後年令とともに増加していることは図 2 で明 かである．年令別に年次的增加傾向をみると，

表 1 各国 死亡 順 位

（人口 10 万対）

\begin{tabular}{|c|c|c|c|c|c|c|c|}
\hline & & & 日 $(1956)^{\text {本 }}$ & 冾 & 米 (1951) 国 & $\begin{array}{c}\text { デンマーク } \\
(1953)\end{array}$ & 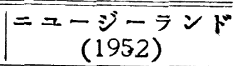 \\
\hline 第 & & 位 & $\begin{array}{l}\text { 中枢神経采の血 } \\
\text { 管摃傷 (153.3) }\end{array}$ & 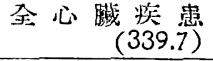 & $\begin{array}{r}\text { 全心 臟 疾 患 } \\
(300.1)\end{array}$ & $\begin{array}{r}\text { 全心藏 疾 患 } \\
\text { (229.7) }\end{array}$ & \begin{tabular}{|l} 
全心臟知患 \\
(295.3)
\end{tabular} \\
\hline & & & $\begin{array}{c}\text { 覀性 新 生 物 } \\
(86.4)\end{array}$ & $\begin{array}{r}\text { 悪 性 新 生 物 } \\
(199.5)\end{array}$ & $\begin{array}{c}\text { 琹 性 新 生 物 } \\
(140.5)\end{array}$ & 悪 性 新 生 物 & $\begin{array}{r}\text { 墨性 新生 物 } \\
(149.3)\end{array}$ \\
\hline & 3 & & $\begin{array}{l}\text { 老 } \quad \text { 衰 } \\
\end{array}$ & $\begin{array}{l}\text { 中枢神経系の血 } \\
\text { 管摃傷 (157.9) }\end{array}$ & $\begin{array}{l}\text { 中枢神経系の血 } \\
\text { 管摃甥 (106.6) }\end{array}$ & $\begin{array}{l}\text { 中枢神経系の 血 } \\
\text { 管摃傷 (126.6) }\end{array}$ & $\begin{array}{l}\text { 中枢神経系 } \\
\text { 管摃甥 (11 }\end{array}$ \\
\hline & 4 & & $\begin{array}{r}\text { 全心藏装患 } \\
(67.7)\end{array}$ & $\begin{array}{l}\text { 肺炎及び気管支 } \\
\text { 炎 (104.4) }\end{array}$ & $\begin{array}{r}\text { 不虑の 䨡 故 } \\
(62.5)\end{array}$ & $\begin{array}{r}\text { 不慮の雪故 } \\
(41.7)\end{array}$ & $\begin{array}{l}\text { 不虑の軎故 } \\
(42.7)\end{array}$ \\
\hline & & & 全 臨 $\quad$ 核 & $\begin{array}{r}\text { 不感の事故 } \\
(32.3)\end{array}$ & $\begin{array}{l}\text { 肺炎及び気管支 } \\
\text { 炎 (28.8) }\end{array}$ & $\begin{array}{l}\text { 肺炎及び気管支 } \\
\text { 炎 }(25,6)\end{array}$ & $\begin{array}{l}\text { 肺炎及び気管支 } \\
\text { 炎 }\end{array}$ \\
\hline
\end{tabular}


高年令層の增加が著しい，これは若年令層に 多いリユウマチ性心臓疾患, 急性, 亜急性心 内膜炎なとの死亡率が減少し，高年令層に多 い冠状動脈疾患, 心筋变性の死亡率が增加し たためである。

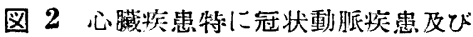
狭心庭の年令別死亡等

（嚁 和 31 年）

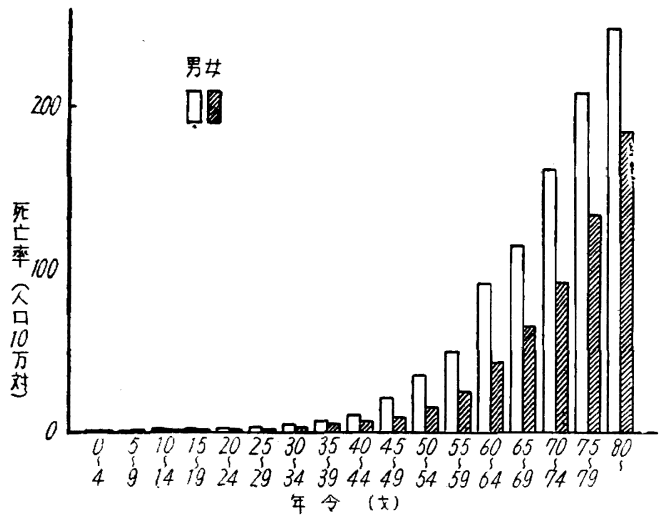

iii) 性

男子はつねに女子の 1.6 倍前後の死亡率で 年令階級別にみると図 2 で見られる通り 40 才 ～64 才で男子の心臟疾患死亡率は女子の 2 倍 以上になつている。但し病類別にすると特に 心内膜炎による死亡者では図 3, 図 4 の如 $<20$ 才から50才迄の年令層で女子が男子の死亡率 を上廻つている。

图 3 急性, 覀急性心內膜炎死亡の 性，年令分布

（炤和 29 年）

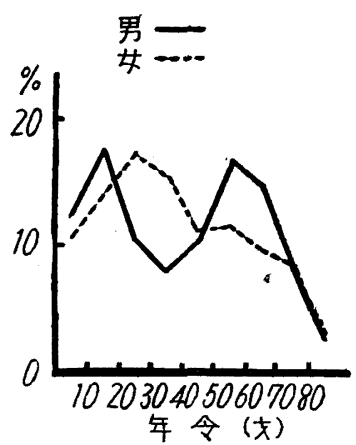

図 4 慢性心內膜炎死亡の性，年令分布

(嚾和 29 年)

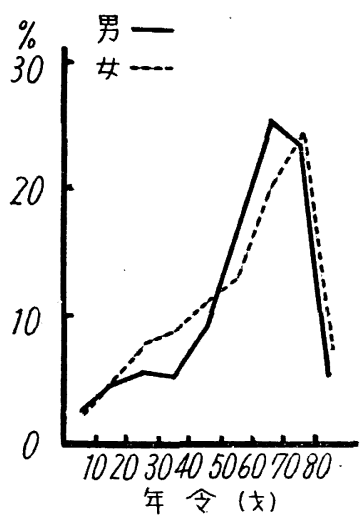

iv）民族

日本人の心臟病死亡率は米国人に比べ男子 約 7 分の 1 ，女子は 5 分の 1 とい5 低率である。 米国（1948 年）の心臓病死亡率を日本 (1952 年）のそれと比較すると，(但し昭和 25 年の日 本人口に標準化) 夫々 $322.7,62.4$ で日本を 100 とすると，米国は517 とい5高率である。全 死亡に対する割合で見ると，米国では $19.9 \%$ ，

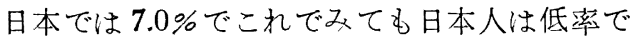
あることが明かである。

v) 栄養

脂肪摂取量の減少していた戦時中（昭和 15 年以降）心藏病死亡率は著しく低下している。 戦後栄養調査成績によると国民一人一日当り 脂肪摂取量は年々增加しているが，心臓病死 亡率もそれと平行して増大している，又昭和 32 年の国民栄養調査成績を府県別に集計し府 県別動脈硬化性及び 変性性心臟疾患訂正死亡 率との相関係数を計算すると $\mathrm{r}=+0.3$ でとく に脂肪摂取量と正の相関関倸が認められる（図 5).

\section{vi）地域}

昭和 25 年より 30 年迄の最近 6r年間の人口 動態統計より国際簡単分類番号，B.28「心藏 病を伴 5 高血圧症」及び B.29「心臓の記載の ない高血圧症」をもとにして高血圧症死亡者 中，心臟病を伴 5 ものの頻度をみると全国的 
図 5 府県別脂肪攝取量と動脈硬化性

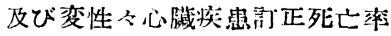
との閣你

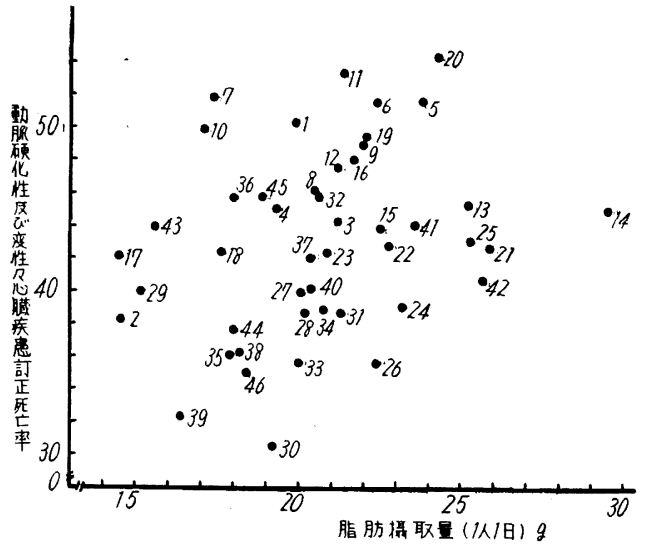

には年次の進むにつれて増大するが，府県別 に観察すると昭和 25 年では岩手県だけ $20 \%$ で他は 10\%以下, 29 年に至ると青森県はすで に $31 \%$ を越光，20\%以上の県は茨城県, 群馬 県, 島根県, 愛媛県, 宮崎県の 5 県を算した。 以上 6 ケ年間で 2 ケ年以上 $20 \%$ 以上の高率を 示す県は群馬県及び愛媛県の 2 県であつた。

\section{vii）都鄙}

vi）で用いた人口動態統計による 高血圧症 死亡者中心缄病を併 5 ものの割合を市郡別に みると表 2 の通り 各年度共市部に 高率であつ た。

viii）職業

同様に 高血圧症死亡者中心臓病を伴 5 もの の割合を職業別に観察すると図6 亿示す如く， 昭和 28 年と昭和 29 年計では第 1 位は漁夫で
あり，次で特殊技能工，事務従業者，管理的 職業，専門的技術職業，農夫の順であり農夫 は6位であることが注目される。

図 6 職業別にみた高血圧死亡者中 心藏病茯件うるのの割合

（嚾和 28 年十炤和 29 年）

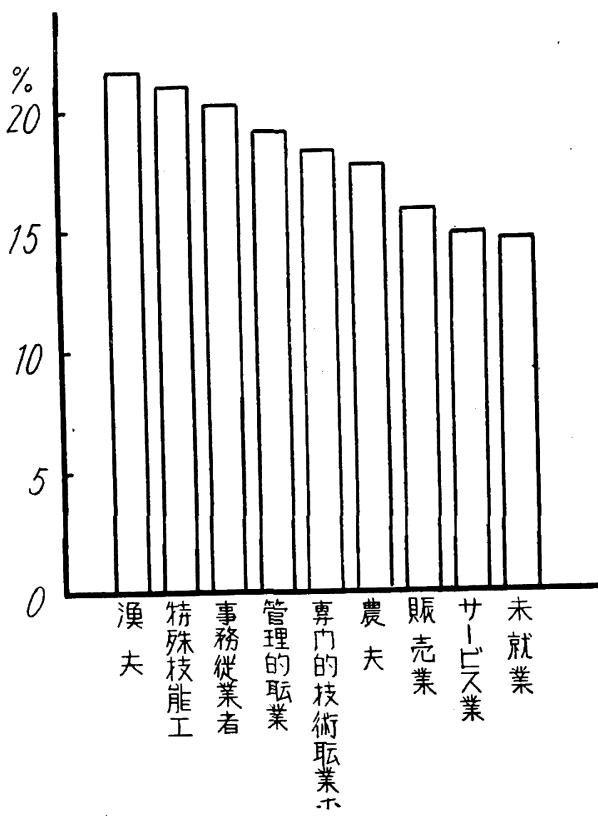

ix）産 、業

産業別に同様の観察を行 5 , 昭和 28 年と 昭和 29 年計では, 図 7 の如く第 1 位は漁水産 業，運輸・公益事業，鉱業，建設業，サービス 業，農業の順で農業は第 6 位であつた。
x）季
節

高血圧死亡者中心臓病を伴 5 ものの割合と

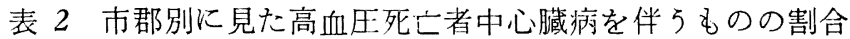

\begin{tabular}{|c|c|c|c|c|c|c|c|}
\hline \multirow[b]{2}{*}{ 年 } & \multirow[b]{2}{*}{ 次 } & 市 & \multicolumn{2}{|c|}{ 部 } & \multicolumn{2}{|l|}{ 郡 } & 部 \\
\hline & & $\begin{array}{l}\text { 高血圧による } \\
\text { 死 し 数 }\end{array}$ & 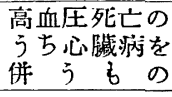 & $\%$ & $\begin{array}{l}\text { 高血圧による } \\
\text { 死 }\end{array}$ & 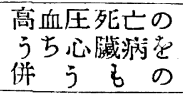 & $\%$ \\
\hline 昭和 & 25 年 & 3071 & 258 & 8.4 & 6859 & 477 & 6.9 \\
\hline " & 26 & 2949 & 301 & 10.2 & 5915 & 516 & 8.7 \\
\hline " & 27 & 3191 & 418 & 13.0 & 5751 & 619 & 10.7 \\
\hline " & 28 & 3367 & 539 & 16.0 & 5973 & 773 & 12.9 \\
\hline
\end{tabular}


図 7 産業別にみた高血圧死亡者中 心瀻病を伴うしのの割合

（昭和 28 年十㸛和 29 年）

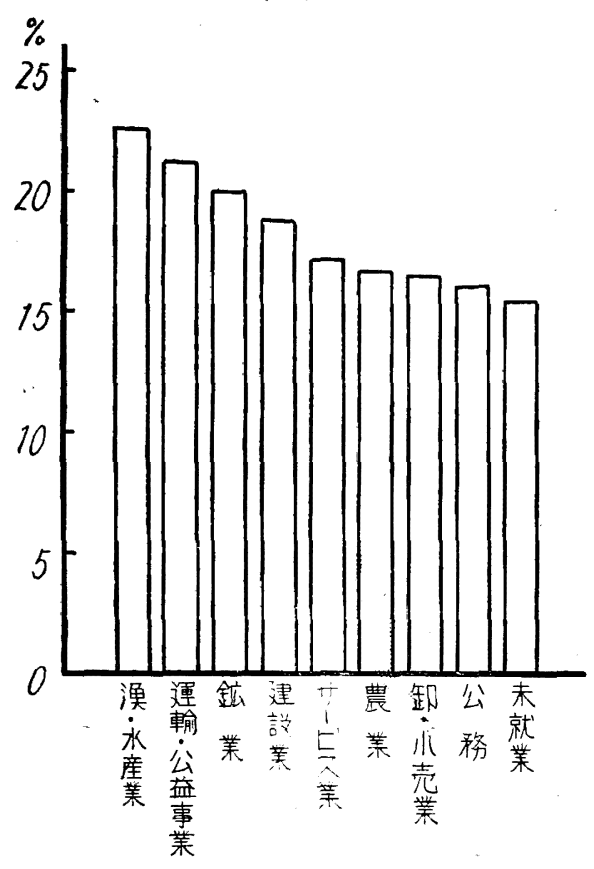

図8月別に見け高血圧死亡者山 心臓病を件うものの割合

(炤和 25 年 30 年平均)

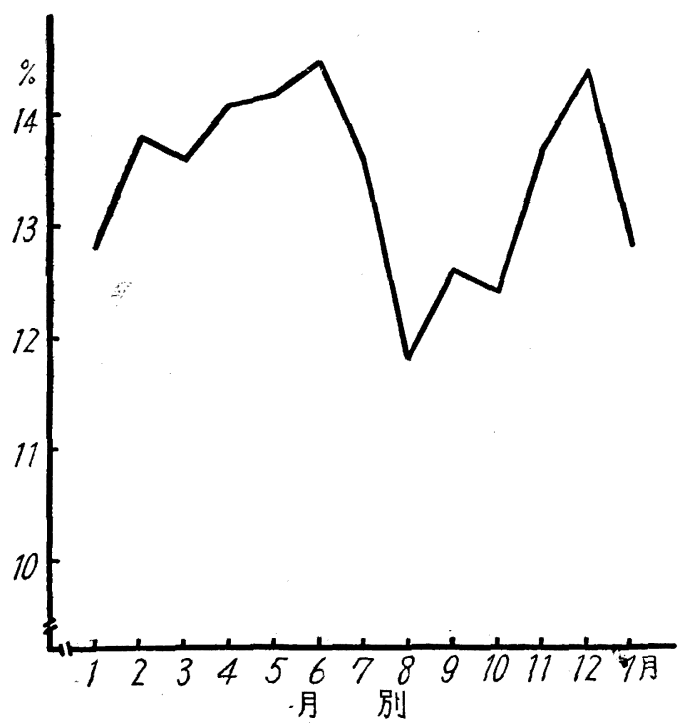

季節との関係を観察するため昭和 25 年から30 年迄の 6r年間の平均月別変動をみると図8の 通りで 11 月から12 月の寒冷開始期と 5 月から 6 月の暑熱開始期の二つの時期に高率であり， 一方 8 月から 10 月にかけて著しい低率を示す ことが認められた。

\section{3. 考察}

大津 3）によればわが国の剖検例からの成績 で冠状動脈硬化をその程度に分けて性，年令 別に観察し，硬化が可なり若年 (30才〜39才) から発現しているといら。こ机は死亡統計で 高年に至つて俄に高率になる事実と対照的で ある、性別にみると宮入4）は心臟病死亡率が 男子に高率であるのは，とくに男子の冠状動 脈が女子に比べ狭窄を起こし易い構造をもつ ているためであるとしている。又性ホルモン との関係も考慮すべきであろ 5 Ｗuest5）は 若くして卵栄摘出術を施した女子では比較的 若年令に冠状動脈硬化を発見するといい， Miller 6) によれば去勢された男子では冠状動 脈硬化の発現頻度が一般に比して低率であ るといわれる。これ等は性ホルモンが直接 或は間接に冠状動脈硬化に影響を及ぼして いることを示すものである。

民族別に日本人に低率なことは，栄養， 食習慣の影響であろらか，米国内に住む白 人之黒人の冠状動脈硬化症は人口 10 万対 白人 512 亿対し黑人 498 で黒人は白人に比 べ低率であり，又米国内の同一地域に住む ユダヤ系人種はイタリ一系人種に比して心 臟病喼者が多い4)。又 Drefuss ${ }^{7)}$ はイス ラェルに住むユダヤ人の各種族間にも発生 頻度に差があると報告している. 栄養特に 脂肪摂取量と心臓病死亡率との間にも関連 性が認められたが，これは Keys ${ }^{8)}$ の観察 した低収入で脂肪椇取量少い民族，集団で は血性コレステロール濃度が低く且冠状動 脈硬化鿊が少ないとい5事実, 及び Wilens 9) の剖検例で観察した肥満体は，やせ 
た人の 2 倍に動脈硬化が 認められた事実と一 致する所見である。職業別にみると高血圧症 死亡の5ちで心臓病を伴 万ものの頻度は漁業 に多かつたが，これは脂肪摂取量が多いこと と関係があるかも知れない.福田 10) は秋田県 の沿岸漁村民は内陸の農村民に比べ高血圧者 の比率は少いが，一方漁村高血圧者には著し い心蔵障害を認め, 左心室肥大の高度の障害 を呈するものが 農村高血圧者に比べ漁村高血 圧者に著しく多いこと，過コレステロール血 者（230mg\% 以上）も男女共漁村に多く農村 に少いことを見出している。この事実は高血 圧発生因子は農漁村により互に異るのではな いか，即ち農村に於ては肉体的負荷は良質笑 養の補償を得ず，高血圧の多発を見るが漁村 に於ては良質栄養のため高血圧発生率は低い が一部の者には脂肪摂取過多となり過コレス テロール血的傾向を産み，これが動脈硬化或 は心臟障害を惹起するのではないかと考えら れている。

一般に心臓病特に冠状動脈疾患発生は座業 の人に多いといわれているが，Morris 11) の バスの運転手と車掌，郵便局の事務員と配達 夫の発生頻度の調查によつても，何れも身体 労作の大きい群は座業的職業に比べ発生頻度 が低く，更に軽症のものが多かつた。季節別 にみた心臓病の死亡頻度は 11 月から 12 月の 寒冷開始期と 5 月から 6 月の暑熱開始期の二 つの時期に高率に認められたが，同様の事実 は米国でも1926年すでに Wolff と White 12) により特に冠状動脈硬化症の 剖検例について 認められている. 北の寒冷地方に死し率高い 一方極めて暑いテキサ火州ダレスにも高率で あることが知られている、結局暑さ寒さに向 万時期の適応障碍と関倸があるのではないか と想像される。

\section{4. 小 括}

以上要するに，まづ心臓病の疫学における 死亡統計の示標的意㼁を論じた後，これによ
る観察の実例をのべ，文献的考察を加えた。 死亡統計に示される数字は必ずしも心臓病患 者の総てを包含するものではないが，以上の 実例で明暸なよ5に，一つの重要な疫学的示 標として今後活用される価值を充分有するむ のと考光る。

\section{第 3 章 諸検查成樍による度学的 観察とその方法論的意義}

\section{1. 緒言}

生前心臟病特に狭心症又は心筋梗塞の症状 を全然呈することなく剖検によつて始めて冠 状動脈に栓塞が認められる場合も少なくない。 これ等は通常死し診断書に於て，他の死因が 記入されているのであつて心臓病がその罹病 状況を忠実に反映するものでないことはいう までもない, 各病院, 診療所, 保健所等の施 設に対する䍜病調査及び 各家庭に対する調査 により心臟病の 罹病状況の概略は知り得ると しても広範囲に実施することは容易ではない。 即ち䍜病統計はその包含し得る集団の大きさ， 地域範囲という立場からは死心統計に一步を 譲らねばならない。他方との正確度という点 を考えると, 診断の施設, 能力の完倩した病 院統計以外は集団検診統計に遙かに劣るので ある。心藏病の検査には結核の場合に於ける $\mathrm{X}$ 線間接撮影に匹敵する検査方法はなく，種 々の示標を用いて種々な角度から総てを検討 する必要がある。その示標としては 1) 問診, 2) 聴打診による理学的検査，3）血王測定， 4) $X$ 線胸部撮影，5）心電図，6）尿及び血液 の検査等があげられ，これ等の諸検査の綜合 結果の解析によつて心藏の健尿性が 診断され るわけである。

\section{I. $\mathbf{X}$ 線 検查}

\section{1. 緒言}

$\mathrm{X}$ 線胸部撮影は心臟検診には必要欠くべか らざるものの 1 つである.心臓実大測定法と しては現在， $150 \mathrm{~cm} \sim 200 \mathrm{~cm}$ の遠距離より撮 
影する所謂遠距離撮影法が用いられているが， この場合は心臓の左右両縁をすぎるレントゲ ン線はほほ平行とみなし得るから，心臓実大 測定法と大凡同様の結果が得られる。然しこ の方法は集団検診等で多人数を短時間に行5 場合は簡単に行い難く従つて間接撮影によつ て心蔵検診の行われることが多い。現在の形 式の間接撮影を始めて採用したのは古賀13）层 び de Areu, 中泉 14) であり，相川 15）及び Holfelder 16）が実施するに及び広く行われる よらになり，現在では集団検診と云えばX線 間接撮影と亡でにいわれる様になつて来たが， これは心蔵形態の異常を発見する方法と迄に はなつていない。単に結核の早期発見の対象 としているにすぎいといつても過言ではり い. 一枚のフイルムから出来得るかぎりの籁 囲で異常所見を発見し，それ等の早期治療を 行う様につとめるのが健康管理の真の目的で なければならない。従つて若し $\mathrm{X}$ 線胸部間接 撮影で，遠距離撮影と同様の確実性或はそれ に近い確実性をもつて心臓疾患の発見が可能 ならば，心臓病健康管理に貢献する所大であ る。間接撮影は管球焦点と螢光板との間の距 離が近いため心藏が拡大され歪をもつて来る のであるが，Hirsch 17）は $35 \mathrm{~mm}$ 版間接撮 影像に於て心臓の形態, 位置の概放の判断が 可能であり更に適当に修正すれば心臓実大測 定も可能であることを暗示して以来, Thompson \& Jellen ${ }^{18}$ ), 遠山 19）が夫々独自の方法 を発表している。白石・清瀬 20) はX線実大像 と間接撮影像との関係を検討して 後者の桩大 修正法を発表して臨床的応用に供し得るとし ている。

著者は以上の事実よりX線胸部間接撮影像 より Moritz ${ }^{21)}$ 飞従つて Mr, ML, Lb, Tr を夫々算出（正中線から最大の距離にある心 臓陰影の左右両縁の長さを求め夫々 $\mathrm{ML}, \mathrm{Mr}$, ML と Mr の和を $\operatorname{Tr}$, 両側胁膜補足腔間の距 離を $\mathrm{Lb}) \mathrm{L}, \frac{\mathrm{Tr}}{\mathrm{Lb}}>0.50, \frac{\mathrm{Mr}}{\mathrm{Lb}}>0.18, \frac{\mathrm{ML}}{\mathrm{Lb}}$
0.33 を夫々心肥大, 右心肥大, 左心肥大 221 として観察を行つた。この方法を用いると今 迄行われて来た肺結核を主とした 集団検診の 間接撮影フイルムをそのま〉使用出来るわけ である。心蔵病がその形態上の変化を現わす に至る場合は病状がすでに担当進行している 場合が多く， X線の肥大をまつて診断するこ とは早期発見といら意味に於てはすでに手拉 くれの感があるが，結輆検診を目的としたフ イルムで容易に検討し得る利点があるので疫 学的観察の示標としてはすてがたい価值をも つている。

\section{2. 観察の実例}

$\mathrm{X}$ 線胸部間接撮影による心臓疾患の 観察は 埼玉県比企郡高坂村の住民 2397 名に対して, 肋膜癒着等により計測不能の者を除き Moritz の係数を算し, $\frac{\mathrm{ML}}{\mathrm{Lb}}>0.33, \frac{\mathrm{Mr}}{\mathrm{Lb}}>0.18, \frac{\mathrm{Tr}}{\mathrm{Lb}}$ >0.50を夫々左心肥大，右心肥大，心肥大と したがこのうち特に左心肥大を主として観察 を行つた。
i) 年
令

$\mathrm{X}$ 線胸部間接撮影像より Moritzの係数で 左心肥大 $\left(\frac{\mathrm{ML}}{\mathrm{Lb}}>0.33\right)$ の割合は図 9 の通り で 40 才未満では 1444 名中 86 名 $(5.9 \%)$ と低 率であるが，40才代では 385 名中 51 名 (13.2 \%)，50才代では 320 名中 60 名 (18.7\%)，60 才代では 186 名中 40 名(21.5\%)，70 才以上に なると 63 名中 19 名 $(30.1 \%)$ と年令の進むに つれて心肥大の割合も增加する傾向を示して W.

ii）性

被検者 2397 名中男子は 1040 名で左心肥大 $\left(\begin{array}{l}\mathrm{ML} \\ \mathrm{Lb}\end{array}>0.33\right)$ は 36 名 $(3.5 \%)$ ，一方女子は 1357 名中 220 名 (16.2\%) で男子に比べ女子に 滛かに高率であることは注目に価する（図9）。 この農村婦人に心肥大者の多い事実は農村婦 人が農業労働の他に家事, 育児という男子よ 
図 9 性別年命別に見け左心肥大者の割合 $\frac{\mathrm{ML}}{\mathrm{Lb}}$

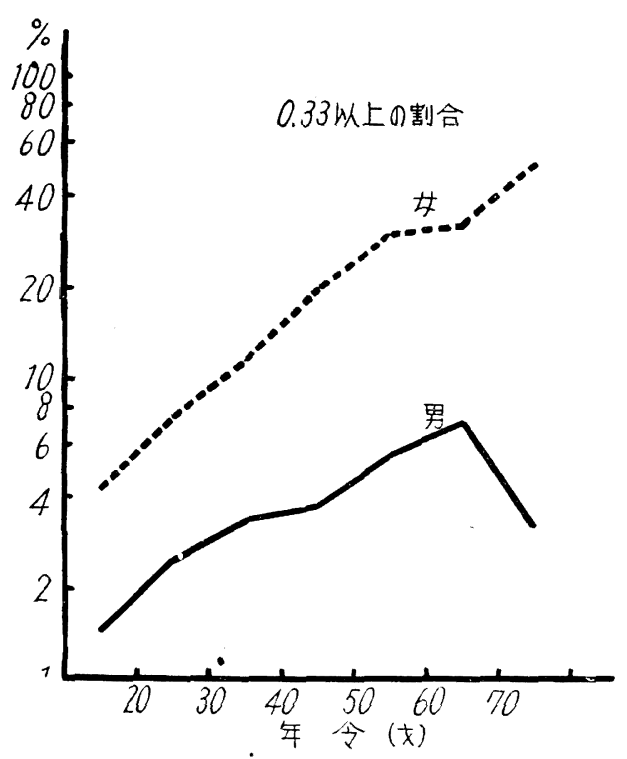

図 10 体重别心肥大
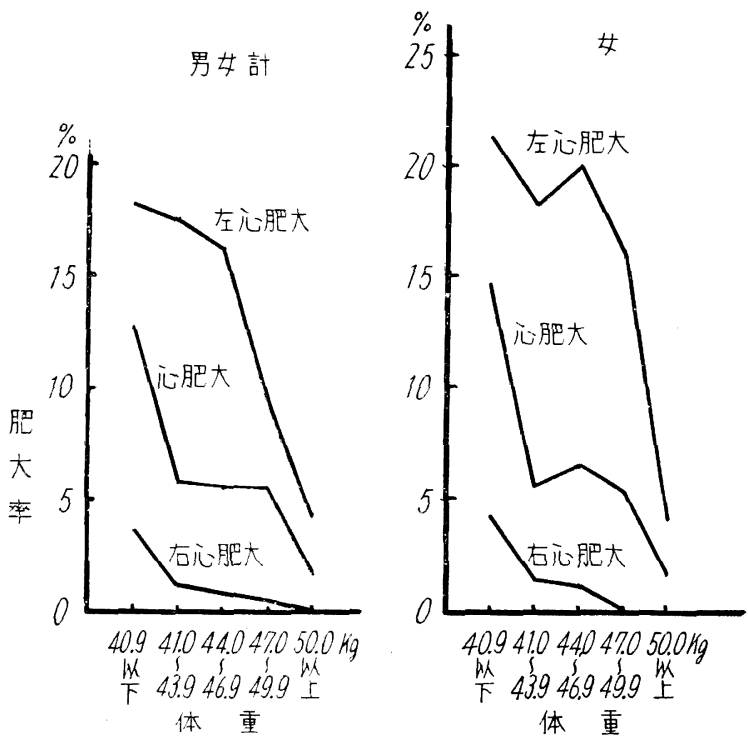

体重

大, 中, 小, 体型を肥满型, 筋肉型, やせ型 にそれぞれ分類し，更に体重測定を行つてそ の各々と $\mathrm{X}$ 線上心肥大との関係を観察した。

Moritz の倸数で左心肥大をもつて検討する と，栄養状態では左心肥大を示寸割合は， $\mathbf{A}$ では 155 名中 10 名 $(6.4 \%), B$ では 482 名中 45 名 $(9.3 \%)$, C では 9 名中 1 名 $(11.1 \%)$ で, 栄養状態の悪いもの程 $\mathrm{X}$ 線上肥大者が多く, 体格では大の者は 50 名中 2 名 $(4.0 \%)$, 中の 者は 583 名中 51 名 $(8.7 \%)$, 小の者は 29 名中 4 名 $(13.7 \%)$ で体格の悪いもの程心肥大者が 高率であつた。更に体型で見ると肥満型 67 名 中 6 名 $(8.9 \%)$, 筋肉型 433 名中 40 名 $(9.2 \%)$, やせ型 56 名中 4 名 $(7.1 \%)$ でX線上心肥大と の明かな関係は見られなかつた。体重との関 係は, 之を 5 群に分けて観察すると図 10 の通 りで, $41 \mathrm{~kg}$ 未満は 50 名中 10 名 (20.0\%)，41 $\mathrm{kg} \sim 43.9 \mathrm{~kg}$ は 85 名中 15 名 $(17.6 \%), 44 \mathrm{~kg}$ $\sim 46.9 \mathrm{~kg}$ は 104 名中 17 名 (16.3\%), $47 \mathrm{~kg} \sim 49.9 \mathrm{~kg}$ では 117 名中 11 名 $(9.4$ $\%), 50 \mathrm{~kg}$ 以上は2 293 名中 12 名 $(4.1$ \%) で低体重群にX線上心肥大者が多 い.X線上の心肥大必ずしも心臓病と は云い難く，農村住民で低栄養による 過労働といらことが心臓肥大を起す原 因となつていることも考えられる。

\section{iv）都鄙}

埼玉県比企郡高坂村に於ける農村集 団検診と，川崎市内某鉄工場に於ける 都市棐団検診とを比較して見ると，農 村ではX線上 Moritz の係数で左心肥 大の割合は $3.5 \%$ であり都市に於ける それは $14.8 \%$ で都市に高率であつた。

\section{3. 考}

察

従来幾多の業績が「心臓実大測定法 り多くの肉体的負担がかかつていることを考 虑せ齐ばならない。

iii）栄養

栄堎状態を良好の順に A, B, C に, 体格を
と遠距離撮影像」或は「近距離撮影像と遠距 離撮影像との成績比較」などに関し発表され ている、しかし之等の換算は正確に数学的に は行ない得ないものである。その理由は撮影 
条件の差は別としても，

1）心蔵は個人的に形，位置に差があり且心 蔵は非対称的に胸廓内に位置し従つて同じ撮 影条件でもその蔭影の挔大率の個人差が入り 陰影は単なる拡大陰影ではなく不平等の桩大

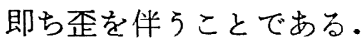

2）フイルムや螢光板と心臓との関係位置を 正しく両方法同一になし難い点.

3）両方法が同一の呼吸位相程度である事の 困難さ 。

4）心蔵周期が両像で差がある事（間接像と 直接像の 撮影時間の著しい差も又誤差の一原 因たり得る。

以上がその正確な数学的計算を困難としかつ 総てを満足せしめる簡単な方程式がなく，徒 つて実用上誤差が少く簡単な方法がよいとい う事になる・Rutstein ${ }^{23)}$ は $70 \mathrm{~mm}$ 間接撮影 法を用いて約 30000 人について心蔵陰影の異 常を検出している．検出率は約 $3.5 \%$ でこ5 ち再検查として一般臨床検査をうけた 845 人 の中, 504 人 $(59.6 \%)$ に心蔵疾思を証明して いる。之は全被検者の $1.6 \%$ にあたる。心蔵 病患者の 55.6\% は無自覚であり, 従つてその 価値は決してゆるがせに出来ないとのべてい る. 又 Green 24) は約 20000 人の対象者で同 様の検査方法を行い, その $7.4 \%$ に心臓異常陰 影をみつけ再検査を受けたもの $80 \%$ に心藏疾 虫を証明している. Thompson 等 18) は 1000 人の検査でその $68.9 \%$ に心疾患を見出してい る. 何れも心疾患の約半数余りが無自覚であ つた。藤江等 25) は国鉄従業員 4000 人に対し 約 $2.5 \%$ に藏陰影の異常を選出している。笹 本等 26.) は某銀行從業員 1873 名中男子 $20 \%$, 女子 $13 \%$ に心臓陰影異常を認めているが，著 者の成績は男子では Rutstein に一致し, 女 子では笹本の成績に近い結果を得た。

\section{4. 小 括}

以上のよ $5 に \mathrm{X}$ 線胸部間接撮影による心臓 検診方法も Mass Screening としては簡単に
してしかも興味ある方法であるしその検出率 もよいのであるから今日広く普通している結 核の早期発見の方法の上5に X 線胸部間接撮 影を利用して心臓, 大動脈陰影の異常をめや すにして心臓病を検出することが意義ある問 題と考兄られる.

\section{II. 心 電 図}

\section{1. 緒言}

心蔵の機能的診断には心電図は欠くべから さるものであり， $\mathrm{X}$ 線胸部間接撮影に比べれ ば時間もかっるし例外的なものと考兄られ易 い. 従つて集団検診に際して必要にして十分 な質の診断を行うため心電計を自由に馳駆す ることは仲々一般には望めないことである。 心電図で我々の知り得ることは，不整脈の認 知，心筋梗塞の証明，心笳障害及び心臓の左 右室別々の過重の表現, ヂギタリス中毒, 心 嘿炎, 肺栓塞等の診断の補助, リウマチ熱等 による急性心筋炎の確認, 心臓神経症の診断 を間接に 助けること及び電解質代謝異常を知 り得ることなどであるが，心臓病の原因を決 定すること迄は困難であり，又心臓の機能容 量を計測出来ない。従つて心蔵疾患の診断は 集団検診の様な種々の検查を行つてその綜合 判断によらねばならないのであつて心電図の 限界も留意する必要がある。著者は種々の集 団検診に際し心電図検査を行い，心電図が心 臓病の没学的観察にどのような役割を演ずる かについて調べた。

\section{2. 観察の実例}

心電図検査に際しては上田等 27) 及び松本等 28）に従つて原則として標準肢誘導（第 I，第 II , 第 II 誘導 $)$, 学極肢誘導 $\left(\mathrm{aV}_{\mathrm{R}}, \mathrm{aV}_{\mathrm{L}}, \mathrm{aV}_{\mathrm{F}}\right)$, 胸部誘導（通常 $\mathrm{V}_{1} \sim \mathrm{V}_{6}$ ) の計 12 誘導を行つ たが，都内某デパート来店者に対する検診の 場合は標準肢誘導及び単極肢誘導のみを行い， 胸部誘導は省略した：これにより集団検診に 際して全誘導を行い得ない場合，最少限度ど 
れだけの誘導を行觉ばよいかについても検討 を加帛た。

i) 年令

川崎市内某鉄工場男子従業員に対する循環 器集団検診に際し心電図検査を行い，心電図 異常者を年令别に観察すると，20才代では 11 名中 2 名 $(18.2 \%), 30$ 才代では19 名中 7 名 $(36.8 \%) ， 40$ 才代で 29 名中 11 名 $(37.9 \%)$, 50 才代で 21 名中 11 名 $(52.4 \%)$ と年令の進む に従つて心電図異常者も增加している。朝日 クリニックカーによる街頭検䛦で行つた心電 図検査成績では心電図異常者は30才代では 20.0\%，40才代で $33.3 \% ， 50$ 才以上では 60.0 \%と增加を示している. 都内某デパート来店 者について検査した心電図異常者は 40 才未満 は79名中 16 名 $(20.0 \%), 40$ 才〜 59 才は 142 名中 37 名 $(26.0 \%), 60$ 才以上は 62 名中 27 名 (43.5\%) と何れも年令の進むに従つて心電図 異常所見率も增加を示している.

ii) 性

著者の行つた種々な集団検診に於ける心電 図検査成績を，都市と農村に分けてその性別 の差を観察すると，図 11 の通りで都市では男 子 306 名中心電図有所見者 123 名 $(34.1 \%)$, 女子は 69 名中 22 名 $(31.8 \%)$ 亿異常者が存在 し，一方農村では男子 95 名中 55 名 (57.8\%)， 女子 135 名中 77 名 $(57.0 \%)$ に心電㘠異常者 が認められた。即ち都市農村共男子は女子に 比べわずかに高率である。

iii）民族

都内某病院来院者中, 日本国内在住の白人
図 11 心霞図有所見等

（都市対票村）

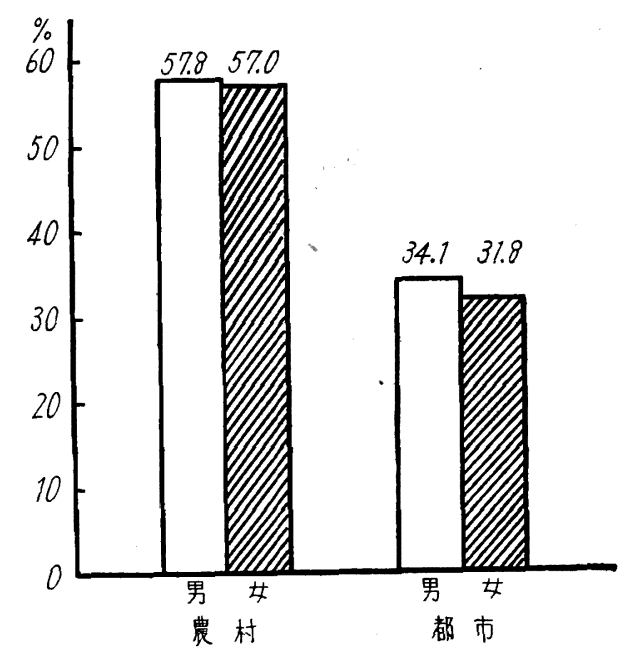

145 名と，同一病院に来院した同様の日本人 について心電図㭘査を行いその成績を比較す ると，表 3 に示す通り心電図有所見率は白人 145 名中 74 名 $(51.0 \%)$, 日本人 145 名中 82 名 (56.5\%) で大差なく，異常所見の内容も共に 期外収縮, フリンメルンが最多で, 特記すべ き差は認められなかつた。この理由の一因と しては, 本検查対象の白人は主としてカトリ ックの神父, 修道女で日本に長期間（長い者 は20 30 年以上）滞在し従つて食䬲, 気候等 日本人に近い状態にあるためであると考えら れる. 結局人種の差とい5よりも食生活とか 身体活動という，生活様式がこの心臓疾患の 発生頻度を左右するものと考它られる。出身 地の影響が移住地に於てもはや認められない という事実は心藏疾患の発生要因として生活

表 3 白人対日本人心電図異常所見

\begin{tabular}{|c|c|c|c|c|c|c|c|c|c|c|c|c|c|c|}
\hline & & & & & & \multicolumn{3}{|c|}{ 心 } & 電 図 & 異 & 常 & \multicolumn{3}{|c|}{ 見 } \\
\hline & & & $\begin{array}{l}\text { 検人 } \\
\text { 查貝 }\end{array}$ & $\begin{array}{l}\text { 心正 } \\
\text { 霜常 } \\
\text { 基者 }\end{array}$ & 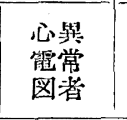 & $\begin{array}{l}\text { 右 } \\
\text { 照 }\end{array}$ & $\begin{array}{l}\text { 左 } \\
\text { 萌 } \\
\text { 犬 }\end{array}$ & $\begin{array}{l}\mathrm{P} \\
\text { 界 } \\
\text { 常 }\end{array}$ & $\begin{array}{c}\text { ST. T } \\
\text { S } \\
\text { 異 } \\
\text { 常 }\end{array}$ & 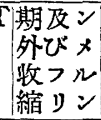 & $\begin{array}{l}\text { 脚ッ } \\
\text { ブ } \\
\text { ロク }\end{array}$ & $\mid \begin{array}{l}\text { その障 } \\
\text { の侄 } \\
\text { 他遒碍 }\end{array}$ & $\begin{array}{l}\text { 低位 } \\
\text { 霞差 }\end{array}$ & $\begin{array}{l}\text { 洞整 } \\
\text { 不脈 }\end{array}$ \\
\hline 白 & & 人 & 145 & 71 & $\begin{array}{c}74 \\
(51.0 \%)\end{array}$ & 1 & 7 & 6 & 16 & 20 & 9 & 13 & $\rightarrow$ & 1 \\
\hline 日 & 本 & 人 & 145 & 63 & $\begin{array}{r}82 \\
(56.5 \%) \\
\end{array}$ & 3 & 12 & 8 & 15 & 25 & 6 & 11 & 1 & 1 \\
\hline
\end{tabular}


様式や環境条件の重要性を物語るものと思わ れる。

iv）嗜好

a) 煙草

都内某デパート来店者について舫煙者, 非 妿煙者の心電図異常に及ぼす関係を検査した 成績では, 呰煙者 122 名の5ちで心電図異常 者 40 名 $(32.7 \%)$, 非契煙者 161 名の 5 ち心電 図異常者 40 名 $(24.8 \%)$ で，知煙者群にわら かに心電図異常が高率であつた。

b) 酒

同椂汇都内某デパート来店者に対して行つ た調査によると，酒をのむもののうち心電図 異常者は 146 名中 47 名 $(32.1 \%)$ ，酒をのま奴 ものの5ち心電図異常者は 137 名中 33 名 (24.0 \%) で，飲酒者にわづかに高率であつた。

\section{v) 都鄙}

著者の行つた種々の集団検診の心電図成績 を都市と農村に分けてその各々について心電 図異常者の割合を比較観察すると, 埼玉県加 須市, 北葛飾郡松伏村, 北埼玉郡干代田村に於 ける高血圧者のみの心電図検診成績では，そ の $59.2 \%$ が心電図異常であつた。 又都下小平 町で行つた成績では 32 名中 14 名 (43.7\%) が 心電図異常であつた。一方都市に於ける成績 は，川崎市内某鉄工場に於ける男子従業員の 循環器を主とする検診では 80 名中 31 名 $(38.0$ \%) に心電図異常が発見され, 又健康者のみが 来店すると考觉られる都内某デパート来店者

図12心電図暴常所見 左心肥大 心筋障碍

$\mathrm{P}$ 異常不整脈
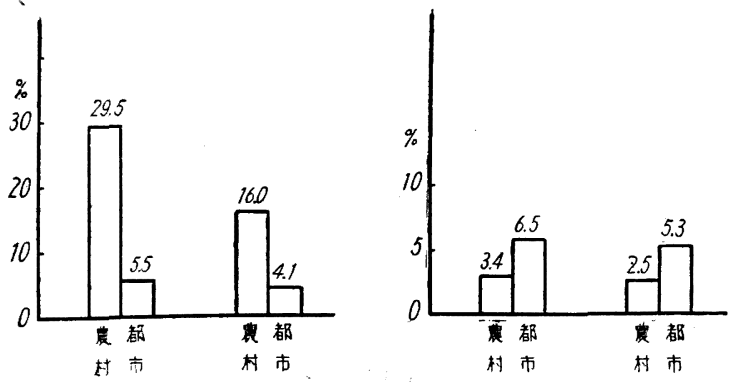

の心電図検査でも，283 名中 80 名で $28.2 \%$ に 異常者を発見した。朝日クリニックカーによ る老人の日の 熖頭検診成績は $50.0 \%$ に異常が 認められた。以上の通り心電図有所見率は図 11 の通り農村の方に 都市より男女共高率であ り内容別にみると図 12 亿示寸如く左心肥大及 び心筋障害 (ST. T 異常) が農村に多く, P 異常，不整脈は都市に多いことがわかつた。

\section{3. 考察}

心臓病の集団検診を目的とする心電図唡査 に関しては古くは Schulz ${ }^{29)}$ 及び Johnson 30)等の記載があるが，何れも健康人を対象と した報告で Schulzは100名中 19\%に，Johnson は 2400 名中 $10.4 \%$ に異常所見ありと

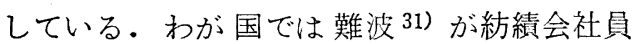
111 名につきその $15.5 \%$ に，荒井等 32）が銀行 員 493 名中 $13.8 \%$ に, 沢田 33 ) は 326 名中病態 $5.8 \%$ ，中間態 $24.3 \%$ といい，広瀬 $34 ）$ は 1524 名中 $10.2 \%$ に夫々心電図異常を報告している. 集団検診で心電図検査を行 定時間内に一定の場所で行はねばならないた め出来るだけ簡単に操作出来る様に ポータブ ル，又記録すれば直ちに読める直記式が採用 されている. 更に標準肢誘導, 単極肢誘導, 胸部誘導の計 12 誘導を行うことは困難な場合 が多いため必要にして十分な最少の誘導が問

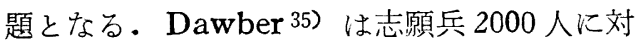
し心電図検査を行い，標準肢誘導に単極肢誘 屗, 胸部誘導の 12 誘導の 時の判定と第 1 誘導のみの判定とを比較し 12 誘導では 臨床的に健康とみられるものの $89.3 \%$ は 正常と適中しているが，健康者の $7.3 \%$ は病的の 疑があり，3.4\% は異常であつ たと，又臨床的にはつきり心疾患と診断 されたものの $53.1 \%$ は電図では正常と されている.之に対し第 1 誘導のみでは 臨床的に健康の者の $80.3 \%$ は正常であ り，9.2\%は病的の疑で $10.5 \%$ は異常と なつている。明かな心蔵疾急ある者の 
$50.7 \%$ は正常とされている。これより明かな 通り第 1 誘導のみでも 12 誘導と略同じ適中率 を示すから，多数例についての検診ではスピ 一ドと技術的簡単さから第 1 誘導のみを実施 すればよいといつている. 山田等 36) は $\mathrm{aVF}$, $\mathrm{V}_{1}, \mathrm{~V}_{5}$ の 3 誘導のみで心電因の異常者の Screening することが可能であると報告して いる．著者は都内某デバート来店者の心電図 検査に際し，上下肢に導子をつけて標準肢誘 導及び単極肢誘導のみを行い，胸部誘導は省 略して検査したが，28.2\% に異常者を発見し た。胸部誘導は上衣の着脱等により一番時間 と場所を必要とするものであり之を除いた他 の誘導による検査でも一応の精度ある心電図 検査が出来るものと考光る。一方心電図と嘫 好品特に煙草については，Johnson ${ }^{30)}$ は8 812 名の男子について心電図検査を行い，架煙者 群ではその $11.7 \%$ に異常を認め, 非契煙者群 では 7.4\% が異常であり, 異常所見内容別では QRS の 0.11 秒以上の延長が, 鿄煙者群に非哭 煙者群の約 4 倍に存在したとのべている。こ れは心室内伝導障害を意味するもので，著者 の成績に略一致している，都鄙による観察で は都市より農村に心電図異常者が高率であつ た。

\section{4. 小 括}

心電図検查成績加年令, 性, 民族, 嘫好, 都嗗等について舞学的観察を行い，年令では 都市農村共年令の 進むに従つて心電図有所見 率も增加し, 男女の性別では都市農村共男子 は女子に比しわづかに高率であつた。 日本在 住の白人対日本人の比較では特記すべき差は なかつた。人種と云う種族の内因的な相違に よるよりは今日ではむしろ食生活，職業等の 社会環境の差に基くものであろ5と考えられ ているが，著者の成績は之を裏書きするもの といえよう。

\section{III. その他の検查成績}

心蔵病の診断には種々の示標を用いての総
合的判断の必要なことは先に述べた， X 線胸 部撮影, 心電図については疫学的観察を行つ たが，他の示標としては問診，聴打診による 理学的検查, 血液検査, 尿, 血液検查等があ げられる。
i) 問
診

心臓岍検診にあたり自覚症, 既往症, 家族 歴, 酒, 煙草の湠好品について調査表に記入 し診断の助けとすることは一方悛学的考察に も役立つ方法である. 問診の中では既往症が 最も重要で，著者の実施した集団検診成績で 埼玉県比企郡高坂村に於ては何れかの 既往症 あるものは 710 名中 324 名 $(45.6 \%)$ あり,こ のうちで心臓病に関係ある既往症即ち心臓病, 腎藏病, 高血圧症, 脚気, ロイマチス, 梅瑇, ジフテリア等を有するものと，これ等以外の 既往症のあるものとでX線間接撮影上 Moritz の係数で左心肥大を示したものの割合は前者 で 92 名中 12 名 $(13.0 \%)$, 後者では 232 名中 23 名 $(9.9 \%)$ であつた。川崎市内某鉄工場及 び都内某デパート来店者についての既往症調 査では上記の心臓满に 関係のある既往症を有 するものは夫々 28 名中 13 名 $(46.4 \%), 104$ 名 中 32 名 $(30.7 \%)$ に心電図上異常所見を認め, 他方既往症ないものの5ちでは夫々 273 名中 94 名 $(34.6 \%), 179$ 名中 48 名 $(26.8 \%$ ) に異 常所見が発見された（図 13）。これ等の成績は 問診の意義を物語るものといえよう。同様の 検査を自覚症について行つたが，（図 14）に示 寸通り $\mathrm{X}$ 線上の心肥大, 心電図異常共自覚症 の有無では殆んど差がみられなかつた。

ii) 理学的検査

心臓病の検診で特に聴, 打, 触診による理 学的所見が大切で，このらち特に重要なのは 心音聴取であり，著者の埼玉県比企郡高坂村 の農村住民検診にあたり，第 II 肺動脈音 $\left(\mathrm{P}_{2}\right)$ と第 II 大動脈音 $\left(\mathrm{A}_{2}\right)$ とを比較し， $\mathrm{P}_{2}>\mathrm{A}_{2}, \mathrm{P}_{2}$ $=\mathrm{A}_{2}, \mathrm{P}_{2}<\mathrm{A}_{2}$ の 3 群に分類し夫々についてX 線問接撮影上 Moritz の係数の心肥大との関 係を観察した所， $\mathbf{P}_{2}>\mathbf{A}_{2}$ では $12.6 \%$ に心肥大 
図 13 既往症と心肥大

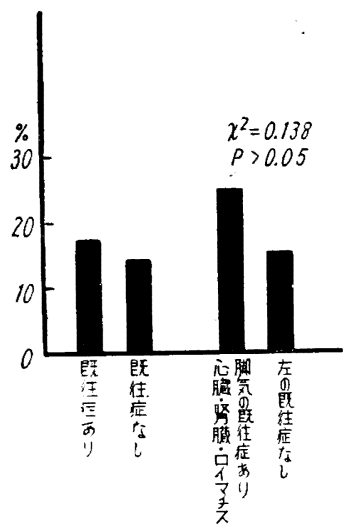

图 14 自覚症と心肥大

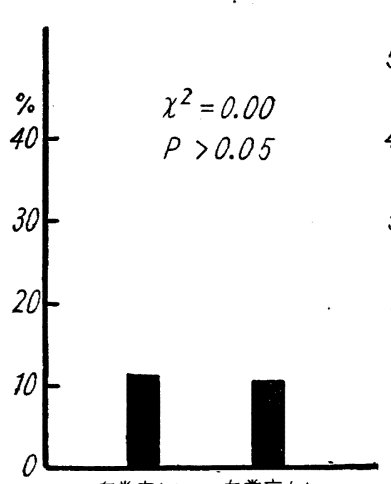

自党症かり自党症ない
既往症 と心電図異常

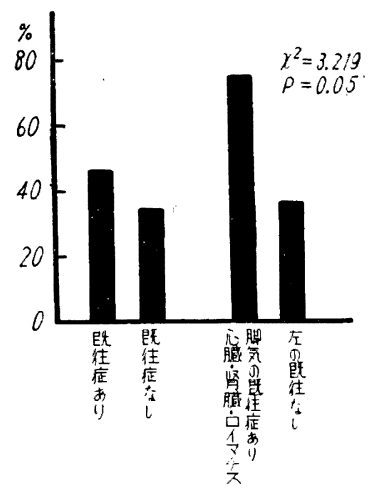

自覚筑 と心電図異常

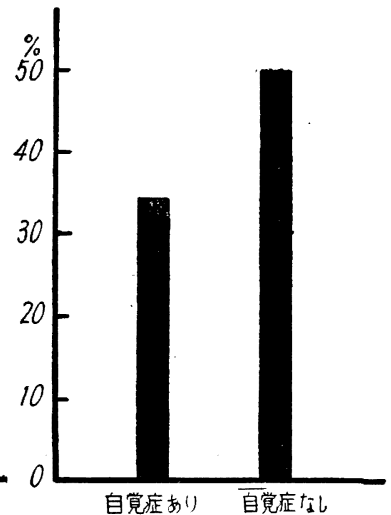

血圧測定は簡単に行われるため心蔵 疾患の集団検診には第一に応用され る。収縮期圧, 拡張期圧の測定は勿諭 であるが，この両者からさらに平均血 圧を算出することが必要で，これは実 際には雪気血圧計で血圧曲線を描かせ て算出するのであるが，臨床的には （拡張期圧 $+\begin{gathered}\text { 脈圧 } \\ 3\end{gathered}$ ）の式から計算し その近似值を求めている。高血圧につ いては学者により多少限界值に差はむ るが，毎回の収縮期圧が $150 \mathrm{~mm}$ 以上 あればまづ高血圧と考えてよいようで ある。従つて高血圧, 低血圧とも色々 の因子を考慮して平均血圧には多少の 幅を置くべきである．著者は以上の点 から血圧の正常範囲は, 収縮期圧 110 $\mathrm{mm} \sim 150 \mathrm{~mm}$, 平均血圧で $90 \mathrm{~mm} \sim$ $110 \mathrm{~mm}$ として観察した。川崎市内某 鉄工場従業員に対する検診で最高血圧 $150 \mathrm{~mm}$ 以上のものと未満のものとで は心電図上異常所見を有するものは図 15 の通り夫々 32 名中 16 名 $(50.0 \%)$, 43 名中 13 名 $(30.2 \%)$ で高血圧者に有 所見率が多い.X線間接撮影上心肥大

を示し， $\mathrm{P}_{2}<\mathrm{A}_{2}$ では $13.9 \%$ に心肥大を 認めた。血圧との関係を見ると最高血生 $150 \mathrm{~mm}$ 以上の高血圧者中で $\mathrm{P}_{2}>\mathrm{A}_{2}$ は 男子 26 名中 2 名 $(7.6 \%)$, 女子 99 名中 13 名 $(13.1 \%)$ で， $\mathrm{P}_{2}<\mathrm{A}_{2}$ では男子 26 名中 5 名 $(20.0 \%)$, 女子 99 名中 20 名 (20,5\%) であつた。以上の結果からX線 間接撮影上心肥大を呈するものは, 両者 に差が認められないが高血圧との関倸は $\mathbf{P}_{2}<\mathbf{A}_{2}$ の方に高率であることがわかつ た。即ちこの一例からも聴診を含めた理 学的検査が重要な意義を有していること を知り得ると思 5 。

iii）血圧測定
図 15 最高血圧と心肥大最高血圧々心管図異常
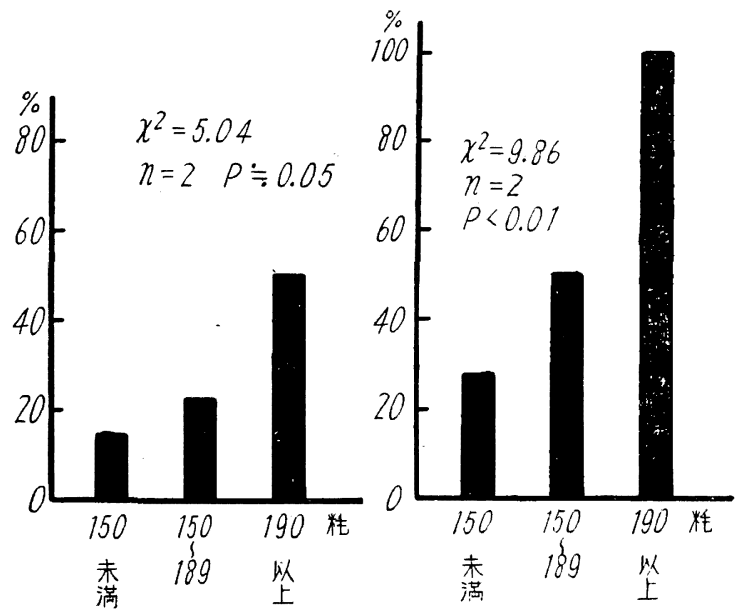
も同様に高血圧者に多い。又埼玉県比企郡高 坂村の検診成績では最高血圧を $150 \mathrm{~mm}$ 以上 と, 未満に分け心肥大との関係について検討 すると表 4 の通り Moritz の倸数上 $\frac{\mathrm{Mr}}{\mathrm{Lb}}$, $\frac{\mathrm{ML}}{\mathrm{Lb}}, \frac{\mathrm{Tr}}{\mathrm{Lb}}$ の何れも, 又男女共高血圧群に 心肥大が高率であつた。

表 4 最高血圧と心肥大との関倸

( ) は女子

\begin{tabular}{|c|c|c|c|}
\hline $\begin{array}{l}\begin{array}{c}\text { Moritz } \\
\text { の保数 }\end{array} \\
\text { 最高血圧 }\end{array}$ & $\frac{\mathrm{Mr}}{\mathrm{Lb}}>0.18$ & $\frac{\mathrm{ML}}{\mathrm{Lb}}>0.33$ & $\frac{\mathrm{Tr}}{\mathrm{Lb}}>0.50$ \\
\hline $150 \mathrm{~mm}$ 未満 & $\begin{array}{c}0.4 \% \\
(0.7 \%)\end{array}$ & $\begin{array}{c}8.1 \% \\
(13.7 \%)\end{array}$ & $\begin{array}{c}7.6 \% \\
(3.7 \%)\end{array}$ \\
\hline $150 \mathrm{~mm}$ 以上 & $\begin{array}{c}1.2 \% \\
(2.3 \%)\end{array}$ & $\begin{array}{c}16.4 \% \\
(30.2 \%)\end{array}$ & $\begin{array}{c}11.3 \% \\
(18.6 \%)\end{array}$ \\
\hline
\end{tabular}

iv）尿及び血液検査

尿蛋白，尿糖，尿ウロビリノーゲン等の検 査も心藏病診断の示標となり，夫々試薬によ り簡単に検酉出来る。血液は血色素量, 赤血 球, 白血球算定, 血液比重, 血液ワッセルマ ン反応，血清コレステロール測定等の諸検査 があるが 37)，このうちで集団検診としては検 尿, 血液比重 (硫酸銅法), 血液ワッセルマン 反応等が簡単, 迅速に行はれる。著者の行つ た川崎市内某鉄工場從業員の集団検診に際し てズルフオサリチル酸法により検尿し，蛋白 尿と心電図異常との関係を観察すると $3.7 \%$ に 蛋白尿を証明し，その全員沁電図異常をみ とめた。埼玉県比企郡高坂村住民検診で蛋白 尿とX線間接撮影上心肥大との関係を見ると， 蛋白陽性者は心肥大者 60 名中 9 名 $(15.0 \%)$ 飞 存在し, 一方最高血圧 $150 \mathrm{~mm}$ 以上の高血圧 者では 120 名中 26 名 (21.6\%) に陽性であつ た。尿ウロビリノーゲン陽性者は被検者 1048 名中 128 名 $(12.2 \%)$ に存在し, 尿糖陽性者は 1048 名中 12 名 (1.1\%) であつた。梅毒性疾患 が心疾患を誘発することは明かであり，血液 ワッャルマン反応の 検査もこの意味で重要で ある.川崎市内某鉄工場の検診で行つた血液
ワッセルマン反応陽性者中, 心電図異常者は $50.0 \%$ であつた，貧血と心臓疾患との関倸に ついて検㚗するためには集団検診では硫酸銅 法による全血比重の測定が最も簡単正確な方 法であると考える.川崎市内某鉄工場での検 診に際して行つた成績では，硫酸銅法により 全血比重 1054 以下の 低比重者 21 名の5ち心 電図異常者が 13 名 $(61.8 \%)$ に見られた。又 朝日クリニックカーによる街頭検診では硫酸 銅 1052 の比重液を用意し，これに血液の一滴 を滴下し，沈下，中間浮遊，浮上に分け，正 常比重, 等比重, 低比重としてこれ等と心電 図異常との関係について観察した所，正常比 重群では心電図異常者は 52.0\%であり，低比 重群では $62.4 \%$ に異常を発見した。以上二集 団に対する成績では何れも低比重者に心電図 異常が高率であつた。

\section{2. 考察}

$\mathrm{X}$ 線検査, 心電図検査を除いた他の示標に は以上のよ5な種々のものがあるが，このう ち最も正確にして重要なものは血圧測定であ る. 高血珐に対する心電図検㚗の集団的応用 に関しては梶浦等 38) は最高血圧 $160 \mathrm{~mm}$ 以 上の 153 名中 $49.0 \%$ に病的所見ありとし，中 馬22）は最高血圧 $150 \mathrm{~mm}$ 以上では 62 名中 $48.3 \%$, 福岡等 39$)$ は 617 名中の本態性高血 圧者の5ち最高血圧 $200 \mathrm{~mm}$ 以上のものは心 電図異常所見が高率であつたとしている。著 者の成績も以上の諸家のそれと略同様に 150 $\mathrm{mm}$ 以上の $50.0 \%$ に心電図異常所見を認め た・高血圧者の心電図所見については守 40) は 257 名中主な変化は軽度 ST, T 異常 $16.3 \%$, 重症 ST, T 異常 $11.6 \%$, 左肥大 $16.7 \%$ ，心房 細動 $9.7 \%$ で高血圧の進行と共に心電図異常も 悪化すると述べている。

\section{3. 小 括}

種々の示標について検討を加えたが，臨床 診断と疫学診断とではその性質を異にし，臨 床診断上必要なことでも疫学上必ずしも必要 
でないことも多く，これ等を如何に組合せて 正確, 迅速, 安価に心臟病の疫学的観察資料 を得るかが重要な問題である．要するに潜在 性心蔵患者の発見に力を注ぐべきであり，自 覚症状なしに㗢いている人々を対象に検診が 行われることが望ましい，これ等の方法が， Multiple Screening といい,心藏淀等の慢性 疾患の集団検診に実施されている。この意味 から問診, 理学的検查, 血圧測定, 尿, 血液 検査等の示標を用いての疫学的観察が必要で ある。

\section{第 4 章 心胴病の疫学に於ける 多角的観察の意義}

\section{1. 緒 言}

第 2 章，第 3 章に拈いて，心藏病の疫学調 查を行 $5 に$ 当つての 観察の示標として死亡統 計, $X$ 線, 心電図, 問誩, 理学的所見, 血圧, 検尿，血液検査等の意義を夫々実例を示しな がら論述した。本章に於ては心臓病の疫学に 於けるいくつかの課題をとらえ，その検討に 当つて，これ等の諸示標がそれぞれ如何なる 意味を持つか，種々の示標を垪用した多角的 観察がいかに有効な研究方法であるかについ て検討を加えた。

\section{2. 研究成樍}

\section{i）年令}

心臓病は高令になるに従つてその頻度が增 すのであるが，この事実は年令別死亡率，X 線間接撮影による Moritz の指数, 心電図有 所見率の河れで見ても明瞭に認められる。但 し年令的差異の大きさは，示標の兄らび方に よつて必ずしも一様でなく，心電図有所見率 でみるとき最も年令差少く， $\mathrm{X}$ 線検査それに 次き， 年令別死亡率に於て最大である。これ は年令が進むに従つて心臓の異常者が増える だけでなく，同程度の異常者の場合でも老令 になる程死亡し易いとい5傾向が存在してい るためと考えられる。

\section{ii）都 骫}

死亡率でみた都嗗差と，X 線, 心電図でみ た都骫差を夫々比較してみると，死亡統計で は市部に高率であり一方 X線上 Moritz の係 数でも都市男子は農村男子に比べ肥大者が多 い傾向がある。然し心電図でみると有所見率 は，農村 $57.3 \%$ ，都市 $33.7 \%$ で農村の方に高 率でむる。心電図の所見を細別して観察する と, $\mathrm{P}$ 異常, 不整脈は, やはり都市の方に高 率に認められた。

要するに都骫の関係は観察の示標の 如河に よつて成績が必ずしも一致しないのである。

iii）性

死亡統計でみると，心藏病死亡率は男子に 高率である。但し病類別に観察すると特に心 内膜炎死亡が成熟期に拈いて女子に却つて高 率となつている。

X線間接撮影上 Moritz の係数では性別で は都嗗で相違することが注目される。即ち農 村では男子に比べ女子に素かに肥大者が多い が，都市ではやはり男子に高率であつた。

一方心電図有所見率をみると，僅かずつな がら都市，裖村共に男子の方に高率である。 要するに女子の方に特に高率に出現すること が注目されるのは農村に於けるX線上Moritz の係数值の場合だけであつた。

\section{iv）栄 養}

死亡統計でみると，府県別脂肪摂取量と府 県別冠状動脈疾患死亡率との間に正の相関関 係が認められる。X線間接撮影上 Moritz の 倸数では肥満型よりむしろやせ型に肥大者が 多かつた。心電図でみると，やはり体重の多 、者程有所見率が高い傾向が5かがわれる.

之を要するにこの場合も X 線間接撮影上の Moritz の倸数值の場合だけが異つた成績を 示すことが注目される。

\section{3. 考察}

性, 年令, 都嗗, 栄養などの諸項目と心臓 淀との関係を死亡統計， $\mathrm{X}$ 線，心電図などの 
種々の示標を用いて観察を試みた。概してい 5 と何れの示標でもほが一致した成績が得ら れたのであるが，詳細に検討すると表 5 のよ うな点が注目される。

これ等を統合して考觉ると，何れか一つの 示標を頼ることなく，事情の許すかぎり多角 的な観察を行い，䛊りない結論をらるよう努 力すべきであると考えられる。

表 5 死流, X線, 心電図の 三者からみた心臓病と諸 要因との関係

\begin{tabular}{|c|c|}
\hline 年令 $\cdots$ 三示標と b一政 & 年命が進屯程高竍 \\
\hline 性 …三示梌と方一玫 & 男子に高经であるが例 \\
\hline & 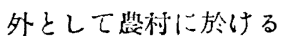 \\
\hline & X線上 Moritz の倸数 \\
\hline & では女子に离桨 \\
\hline
\end{tabular}

都踏…死亡統計，X線では都会に高䉃，心雷図 では帐利の方に高染，但しP罪常，不整 脈は都会に滈䇣

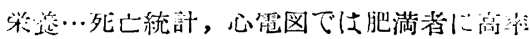

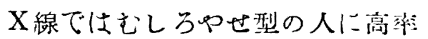

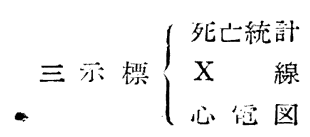

\section{4. 小 括}

心臓病の疫学的観察を行 5 場合, 従来は, 或いは死亡統計, 或いは X 線像, 或いは心電 図と種々な示標が用いられているが，心藏病 の疫学に於ける同一課題（例党ば栄養との関 係）をとらえて，これ等の諸示標を総て用い て垪せ考察を加光た試みは今迄に殆んど見当 らない。このよ5に角度を变えて同一課題を 検討した結果，示標の異なるに従つて異つた 成績が得られることが注目された。これによ つて考えられることは，何れか一つの示標だ けに頼ることなく，多角的観察を行うことは， 心藏病の疫学調查に於て欠くべからさる意義 をもつていると云觉るのである。

\section{第 5 章 心䑏病集団検診方法の検討}

心蔵病集団検診の目的は先づ第一に外見上 健康と思はれる者の中から潜在性の心蔵異常 者を見付け出すことが必要である。しかし今 日わが国では青壮年に対する循環系を主とし た集団検診術式は決定されていない。著者は とくに労衝衛生の分野で集団検診の必要性を 痛感するものである。

i）検査項目の問題

前述した通り肺結核の $\mathbf{X}$ 線間接撮影飞匹敵 する方法は心藏病集団検診にはなく，種々な 検査の総合判断によら齐ばならないのである。 最少の検査項目により最大の 効果をあげるた めに，その必要性の高いものから順にあげる と, 心電図, $\mathrm{X}$ 楾間接撮影, 血圧, 理学的検 査, 問診, 検尿, 血液検查であるが．著者の 行つた種々の集団檢診でも以上の項目を総て 実施することは困難な場合が多いことが明か になつた。即ち血圧測定， $X$ 線撮影，問診等 は短時間に多人数実施出来るが，心電図は一 台一日の検査人員には限度があり，著者の経 験では朝日クリニックカーの衍頭検診，工場 の検診，デパート来店者に対する検診では一 日に殆んど休みなく検查を続けても50〜80人 が限度であつた。剣つて集団検診にあたつて は同時に二台以上の心電計を用いて行 $5 か ，$ 又は日数を要する検査を行らか，又は何れか の方法により Screen された者にのみ心電図 検査を行らか以上何れかの方法をえらんで実 施しなければならない，又同様な点から心電 図の誘導についても全誘導（標準肢誘導，単 極肢誘導，胸部誘導）12 誘導を検査すること がはたして集団検診で必要かどうかも研究す る必要がある。そこで著者はデパート来店者 に対し胸部誘導を除いた 6 誘導を着衣のま 検査しその $28.2 \%$ に異常を発見し得た。これ は胸部誘導をも併せ検査した場合に略匹敵す る数であり充分意味あるものと考壳る。次に Screening の問題で, 最も粗な Screening と しては，調査票に必要事項，特に既往症，自 
覚症, 笓好, 遣伝等を記入してこれにより

Screenする方法であり，著者が朝日クリニッ クカーによつて行つた一例を示せば表 6 に示 す通りである．次に血圧による Screening の 試みは以前より行われ，高血压と考えられる 収縮期圧 $150 \mathrm{~mm}$ 以上の者を Screen し更に 精密㭘査を行 5方法である。X 線間接撮影像 の心蔵肥大より Screen する方法も考兄られ ている．以上の種々の方法があるが，比較的 簡単にして短時間に多人数を正確に検査出来 るものが Screening Test としては理想的で あり, 著者が実施した検査では，自覚症のある もの，心缄に関係のある既往症を有するもの， 高血王あるもの，X 線間接像より心肥大ある ものを Screen し，更に心電図，検尿，血液

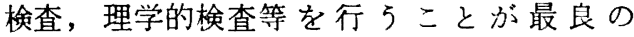
Screening Test と考元る. Arnold 41) は胸部 $\mathrm{X}$ 線問接撮影, 問診, 心電図, 血圧の 4 つの 方法で 858 名に対して心臓病と高血圧に対す る Screening Testを行い,この4つの検査 方法のうちで血圧が最も優れた Screening Test でるとしている. 又 2 つ上の検査項目 の組合せ即ち血圧と $\mathrm{X}$ 線，更に心電図との組 合せが最良の方法であり，これより心臓病は $34.0 \%$ ，高血圧は $78 \%$ に発見されたとのべて いる. 尚この検查に行つた心電㘠は標準肢誘 導の第 1 誘導のみ，血圧は収縮期圧 $150 \mathrm{~mm}$, 拡張期压 $90 \mathrm{~mm}$ を用いている。著者は最初 に行つた川崎市内婪鉄工場従業員 集団㭘診成 續からいかなるものを選んで心電匈をとれば

表 6

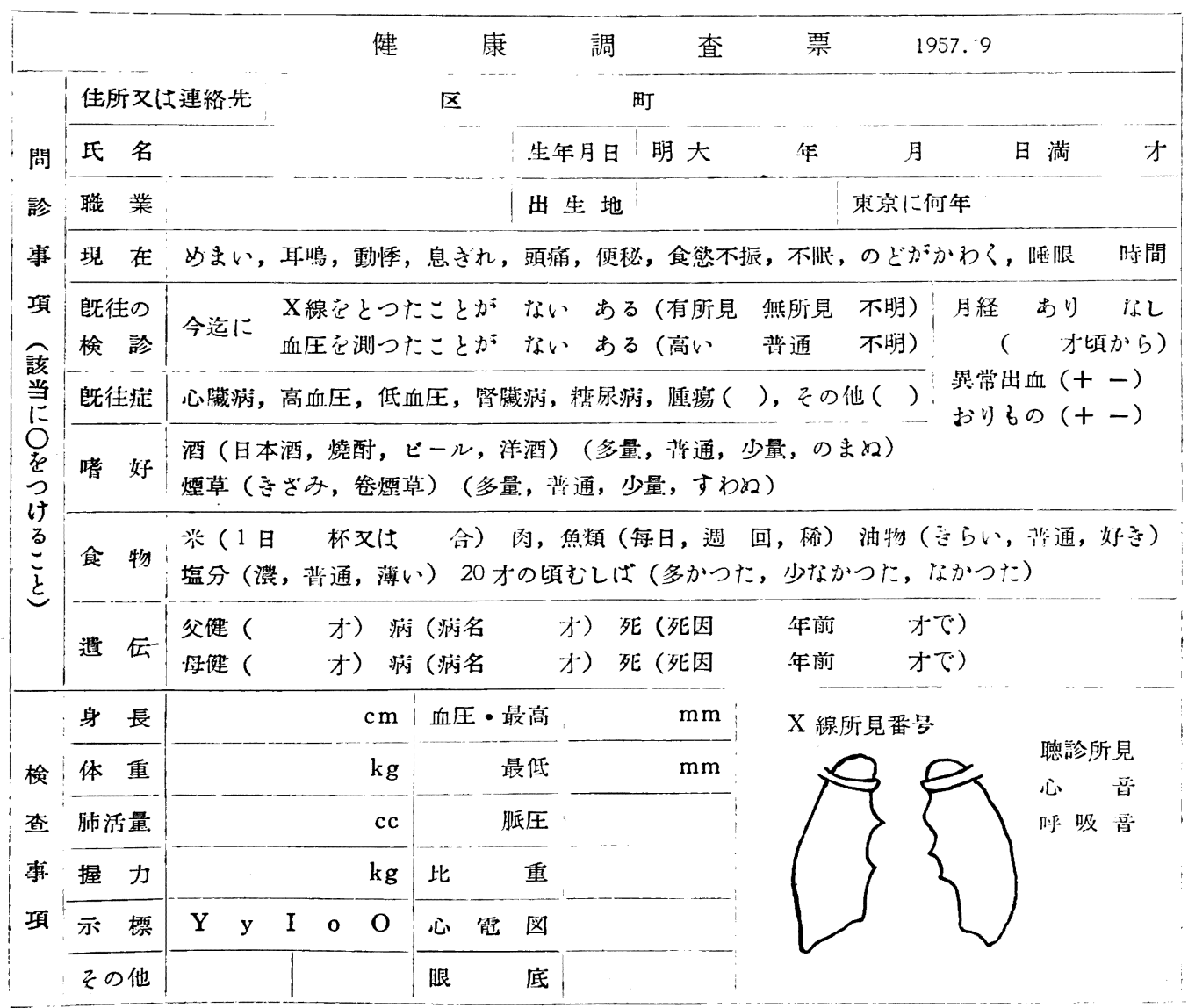


最も異常者を多く発見出来るかを检討したが， 中年以上年令の者，心蔵病に関係省既往症 を有するもの，高血压，蛋白尿を有するもの を選び出して選択的に検査を行えば最も能率 的であることを知つたのである。即ち埼玉県 成人病 検診に際してこの Screening の方法 を用いて心電図検查者をえらんだのであるが $59.2 \%$ の高率に異常者を見出乙得，この Screening 法が满足すべきものであることを 知つたのである。

ii）検查場所

心蔵病集団検診を行うにあたつて考觉られ る場所としては従来病院, 保健所, 学校等が 主として選定されているが，著者等の行つた 朝日クリニックカーによる街頭検診では心電 図の街頭進出とい5点で興味ある問題と考兄 る. 即ち X 線間接撮影が街頭検診の代名詞の 如く考克られているに反し心臓病の街頭検診 は全く行われておらず，今後人の密集地帯に 進出して集団検診を大いに行らべきである。

iii）検租集団

検査集団の選択は検查目的によつて異る。 心藏病の 集団検診の目的としては大別して蔓 延度調査, 要因調亘, 早期発見それに得生教 育の一手段など色々な場合が考光られる。そ の目的の如何によつて検査対象集団は賏るの である，先づ蔓延度調查であるが，この場合 は曲集団を气のま〉代表する標本集団につい て検診する心要がある。悉皆調査を行うか， それとも無作為抽出標本によつて行のが， 標本誤差を最少にするとい5立場から効率の 高い調查方法である。街頭検診や病院, 診療 所に拈ける異常所見率から蔓延度を云々する ことは望ましくない。それらはかたよつた集 団であるからである。要因調㚗の場合は，榆 討しよ5とする諸要因の調査が充分行い得る 集団を選択して実施することが必要である。 例自ば栄養調查が施してある集団について心 電図検查を行らなどはその好例である。

早期発見の目的では，クリニックカーその 他の街頭検診などでも充分役割を果し5る。 特に広く一般民衆に心藏病の重要性を呼びか けるという衛生教育の立場を考虑する場合は
街頭倹診やデパートに於ける検診などが極め て有効な手段であると考号られる。

\section{第 6 章 総括及び結論}

心臓病の形態的及び 機能的健康性を観察す るためには様々の示標が岁り，それ等の示標 を用いて様々な角度即ち宿主，環境の諸要因 を検討する必要がある。 X 線撮影, 心電図, 血圧測定, 理学的検查, 自覚症, 既往症の調 査，尿，血液検查等がその示標である。これ 等を総合して心臓病が診断される。一方死亡 統計も重要であるが，それは心蔵病で死亡す ることが最も著しく健康性を逸脱したものと いえるからである。これ等の心臓の健康性の 異常は集団内の総ての者に起きるものではな い. 性, 年令別については年令の進むに従つ て心臓病は高率を示すが, 20 才から40才の年 令では十子に特に高率に見られることが注目 される。X線間接撮影上 Moritzの係数を算 出し心肥大状沉を観察すると農村では男子に 比べ女子に遙かに心肥大者が多い事実が認め られる。この心肥大を年令, 体格, 栄養等に ついて見ると，年令の進むに従つて高率とな り体格では不良のものが良いものに比べ約 3 倍の心肥大者があり，又栄養では同様に不良 のものに䄪 2 倍の心肥大者が発見された・一 方人種との関係を考壳ると心蔵病死亡率には 米人と日本人との間には相違が著しいが，し かし 都内某病院に来院したわが国内居住の白 人 145 名々，同一病院に来院した同数の日本 人について心電図検查を行つた所，白人 51.0 $\%$ ，日本人 $56.5 \%$ で大差が認められなかつた。 これは対象となつた白人が長期間日本に滞在 しているカトリックの神父，修道女であるた めで人種という内因的相違よりはむしろ 食生 活乞の他の社会環境に基くものであると考穴 られた。又病院来院者と工場等での健康従業 員とを対象に検㚗した成績では心電図巽常者 の比率は夫々 $59.0 \%, 50.0 \%$ となつている. 正 常の勤務者中にも心臓の健康でないものが少 からず発見された。その心電図異常の内容別 では相当の差異があり，病院での場合は不整 脈即ち期外収縮，フリンメルンが，一方工場 
では心筋障害即ち ST, T の異常が夫々最も高 率であつた。これは病院来院者は不整脈の自 覚症を訴えて来ることが多い，工場従業員は 過労等による心筋負荷が原因であるかも知れ ないＸ線間接撮影上心肥大及び心電図異常 者は血圧では最高血圧，最低血圧共何れもそ の高い程高率になり，既往症でも心臓病に関 係の㐫る既往症を有する者に心肥大，心電図 異常が多くなつている。昭和 25 年から 30 年 迄の人口動態統計より，高血圧死亡者を職業 別に分類しそのうちで心臓病を伴うものの割 合を算出すると漁夫に多く農夫に少いのが注 目される。

以上要寸るに分布とい5立場から心臟病に 影響を及ぼす様々な因子について考察したの であるが，更に今後は消長とい5立場から集 団を継続的に追跡観察し，どのうな生活を している人が，どのよ5に生理的状態から病 的状態へ移行して行くかを観察して行くべき であると考学る。そしてこの際の調查集団， 検査方法，調查項目のえらび方及び集団検診 の行い方としては本論文中に種々検討と考察 を加えた方法を用いるべきであると考学る次 第である。

稿さ終るにあたり八田貞義教授に深謝の意き 表し, 種々御教示を頂いた公衆僻生院狻学部松

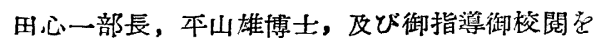
賜わつた乘木秀夫助教授に深了感謝する。

\section{参考文献}

1) United Nation: Demographic Yearbook (1955).

2）厚生大臣官房統計調查部：人口動態統計, 炤 和 25 年 炤和 30 年.

3) 大津：最新医学, 11, 4, (1956).

4) 宮入等: 日本公臬鹳生雑誌, 4, 3, (1957).

5) Wuest, J.H.: Circulation 7, 6, 801 , (1953).

6) Miller, D.: Am. J. Med. Sciences, 223, 3, (1956).

7) Drefuss: Am. Heart J., 45, 749, (1953)

8) Keys, A.: J. Mt. Sinai Hosp., 20, 2, (1953).

9) Wilens, S.L.: Arch. Int. Med., 79, 2, (1949).
10）福田：日本医事新報, No. 1740, (1957).

11) Morris, J.N.: Lancet, 265, 6795, 6796, (1953).

12) Wolff, L. \& P.P. White: Boston M. \& S.J., 195, 13, (1926).

13）古賀：結核, 5, (1936).

14）中泉：世界週報, 350，(1942).

15）相川：結核の臨休，2，4，(1939).

16) Holfelder: Fort. Roent. 58, 2, (1938).

17) Hirsch: Am. J. Roent. 43, 45, (1940).

18) Thompson \& Jellen: Am. Rev. of Tub., 57, 4, 379, (1948).

19) 遠山：新湯医学雑誌, 64, 2, 842, (1951).

20) 白石, 清瀬: 治瘵, 38, 3, (1956).

21）田等：內科レントゲン診断学，1，134, (1947).

22）中馬等：日本公衆衙生雑誌，2，2，(1955).

23) Rutstein, D.D.: Circulation, 4, 5, 641, (1951).

24) Green, M.H.: Am. Rev. tub. supp. 41, 148, (1950).

25）藤江等: 交通医学，10，3，58，(1956).

26）笹本等：日本医事新報，No. 1699，24, (1956).

27）上田等：臨来心篦図学，(1955).

28) 松本等: 臨床心電図, (1954).

29) Shulz: Zeitschr. Klin. Med., 135, Bd. 2, (1938).

30) Johnson: J. of Am. Med. Assoc., 114, 561, (1940).

31 ）難波等：日本偱環器学会雑誌，14，5，6, (1950).

32) 荒井等：日本循環器学会雑誌, 15, 5, (1951).

33）沢田等：日本循環器学会雑誌， $17,3,110$, (1953).

34）広瀬：北海道医学雑誌，30, 4, (1955).

35) Dawber, T. R.: Circulation 5, 559, (1952).

36) 山田等：日本循環器学会雑誌， $21,3,60$, (1957).

37）上田等：臨床検查法，(1951).

38）捤浦等：日本循環器学会雑誌，19，3，106, (1955).

39) 福岡等: 日本循環器学会雑誌, $17,6,320$, (1953).

40）守：日本医事新報, No. 1730, (1957).

41) Arnold, B.K.: J. of Chronic Diseasès, 2, 4, (1955). 
3. Difference between the younger age group and the elder one: the author divided the persons tested into two age groups, i. e. the group of 39 years old or younger, and the group of 40 years old or elder. The values of hue in the three parts of the latter were higher than that of the former, and the values of luminosity of forehead and chin of the latter is significantly lower than that of the former.

4. Difference by occupations: the author compared the akin colour of nurses and that of women working on farm, and only found the significant difference in the hue of cheek and chin of them; i. e. that of the former was lower than that of the latter.

(From the Department of Hygiene, Fukushima Medical Colloge, Fukushima, Japan)

On the Methodology for the Epidemiological Study of Heart Disease

Toshio IsHIBASHI

Although the incidence of deaths resulting from heart disease in Japan is still considerably lower than the of some foreigh countries, a continuous rise in the numer of such deaths is discernible over recent years.

In order to determine the prevalence level and what factors are responsible for this trend, the need for systematic epidemiological studies is indicated. In carrying out such a project, careful methodological consideration should be given to the techniques suitable for the survey as well as to the time, place and person preferably to be selected for studies.

The results, using death statistics, $\mathrm{X}$-ray and electrocardiogramme as the indices of the studies, reported as follows:

1. Age: all three indices indicate that as age increases, the prevalence cf heart disease increases proportionally.

2. Sex: death statistics and E.C.G. show that a higher percentage of men suffer from heart discase, while X-ray reveal that the percentage of hypertrophy is higher in female than in male especially in rural district.

3. Urban \& rural relations: death statistics and X-ray show a higher prevalence of the disease in urban area, while E.C.G. indicate a higher percentage of prevalence in rural district. In the case of abnormal $\mathrm{P}$-wave and arythomia, however, the percentage is found higher in urban area than in rural district.

4. Diet: death statistics and E.C.G. indicate a higher prevalence among overweight-persons, though X-ray indicate a higher rate of hyphertrophy among underweight-persons.

5. Nationality: there is no marked difference in the percentage of abnorma- 
lity in E.C.G. among occidentals living in Japan and Japanese people. It is likely that the similarity in diet ar $\mathbf{d}$ in climate plays a greater rule than the difference in nationality.

6. Profession: in the case of those who died with hypertension, a greater numer of fisherman had heart dis sase than the other profession. This might again indicate this strong influence or diet.

7. Season: the six years average figure of the death rate from heart disease in Nov. \& Dec. and al.so in May \& June than in Aug. \& Sep. indicating the intimate relationship $b$ stween the occurrence of death from heart discase and the maladaptation to the changing climate.

(From the Department of Hygiene, Nippon University Medical School, Tokyo, Japan)

Studies on the Farmer's Dwelling in Toshima Island of Izu

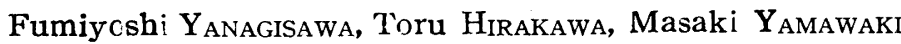

Morio Morozumi \& Masao Suda

The authors made an investigation and analysis of farmer's dwelling in Toshima Island, one of the isolated island of the Seven Islands of Izu. The physical feature of the Island is characteristic because of steep cliff surounding the Island and a poor expansion of level area. Due to strong seasonal winds and rain, villages are located on the hilly part rich in groves of trees. According to the investigation performed, the following results were rea hed:

1. The area of the residential part is 598 sq. meter (180.8 tsubo) on the average and the floor space of the main dwelling average 80.3 sq. meter $(24.3$ tsubj) which means that houses are small in comparison to the siz or the land.

2. The lengih of time afier the dwellings were built, is 40.9 years in average.

3. The number of room found 4.1 per house and size of rooms per total space of house, $39.4 \mathrm{sq}$. meters (23.2 Joo) which is comparable to the size of room of forming vil'age in othər district but the number of inhabitants was found as 5.4 persons per house, which is less than in elewhere. Hence, the usable room space is $7.3 \mathrm{sq}$. meters $(4.3 \mathrm{~J} \mathrm{o})$ per person which is larger than the national average of 6.1 sq. meter (3.6 Joo).

4. The dwellung of the aged are detached.

5. The scale of farming is small and means of production are limited ant the size of attached buillings (earthen store rooms, store housa and barns) is not large.

6. The details of the dwellings, for example, kitchen, water supp!y, toilet and such things as location of barns, lighting and ventilation should resonably be improved.

(From the Institute of Rural Welfare, Tokyo Medical \& Dental University, Tokyo.) 